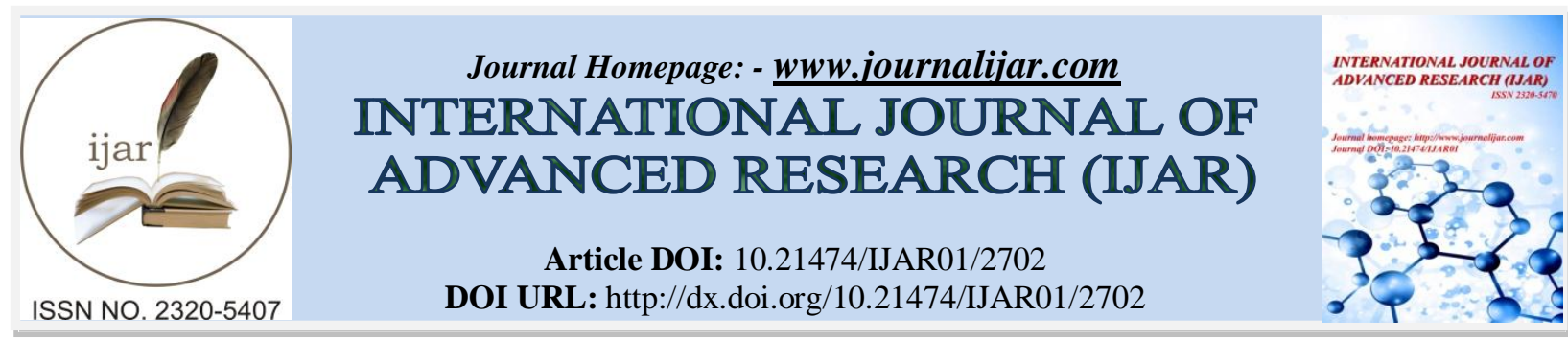

RESEARCH ARTICLE

\title{
ISOLATION AND IDENTIFICATION OF URIC ACID DEGRADING BACTERIA, OPTIMIZATION OF URICASE PRODUCTION AND PURIFICATION OF URICASE ENZYME.
}

Femi Kariy Atty and Jini JosepH*.

Department of Biotechnology, St. Peter's College, M.G University, Kerala.

\section{Manuscript Info}

\section{Manuscript History}

Received: 31 October 2016

Final Accepted: 01 December 2016

Published: December 2016

Key words:-

Uricases,Gout, 16srDNA, BLAST,

Dialysis, PCR.

\section{Abstract}

Uricase plays an important role in the medical field, such as in biochemical diagnosis, where it is utilized as a reagent for uric acid detection in serum, urine and other biological fluids and in biosensors that can readily detect uric acid more specific, accurate and sensitive than the other methods. Furthermore, uricase can be used as a protein drug for reducing toxic urate accumulation in diseases such as gout. The aim of the present work is to isolate, identify and purify uricase enzyme from bacteria as well as optimize the medium and cultural conditions for maximum enzyme production. The uricase producing bacteria was isolated from different environments in and around Ernakulam Dist, Kerala. Uricase activity was initially identified by the formation of halo zone in uric acid incorporated medium. The potential uricase producing strain was then identified by cultural, morphological and biochemical analysis. Further, the identity of the strain was confirmed by PCR reaction of $16 \mathrm{srDNA}$ primers, sequencing and then by the BLAST analysis. The results showed that the isolated bacteria had highest homology (99\%) with Ochrobactrum anthropi.The isolate was then evaluated by submerged fermentation for enzyme production. Submerged fermentation process was carried out under different $\mathrm{pH}$, temperature, salinity and under different carbon and nitrogen sources to find out the optimum conditions. The optimization studies showed that the maximum enzyme activity was (0.0409 IU/mg protein) at $40{ }^{\circ} \mathrm{C}$ temperature. The enzyme produced under all the optimum conditions was partially purified by ammonium sulphate precipitation, dialysis and DEAE ion exchange chromatography. The final purification after DEAE ion exchange chromatography yielded specific activity and fold purification of $0.0455 \mathrm{IU} / \mathrm{mg}$ protein and 1.26 respectively.

Copy Right, IJAR, 2016,. All rights reserved.

\section{Introduction:-}

Urate oxidase or uricase (urate: oxygenoxido reductase, EC 1.7.3.3) is an enzyme in the purine degradation pathway. Various medical conditions increase the amount of uric acid in biological fluids. Such conditions can lead to gout, chronic renal disease, organic acidemias and Lesch-Nyhan syndrome (Su-Hua Huang and Tung-Kung Wu, 2004). Also precipitation of urate crystals leads to renal calculi, intestinal necrosis, and skin calcification (Mona et $a l$., 2015). In the case of gout associated with renal complications, direct injection of urate oxidase is also being 
preferred. Such injections prevent hyperuricemia disorders that may occur during chemotherapy. Thus, uricase is a promising enzyme in the medical field.

Uricase is mainly localized in the liver of animals and inside microorganisms such as Bacillus pasteurii,Proteus mirabilis, and Escherichia coli. Several investigators studied the purification and characterization of uricase enzyme by microorganisms (Atalla et al., 2010). Ammar et al (1987) stated that Streptomyces albosriseolus potentially produced uricase in media that contained uric acid as the main source of carbon, nitrogen, and energy.

The recombinant expression of uricase from $P$. aeruginosa in $E$. coli, also showed higher activity than other uricases isolated from different microorganisms (Mona et al., 2015). Further, recombinant uricase from Candida utilis was successfully expressed in Hansenula polymorpha under the control of the methanol oxidase promoter using Saccharomyces cerevisiae alpha-factor signal peptide as the secretory sequence. Pegloticase (commercial uricase) is a recombinant uricase used to lower the levels of uric acid. (Magda et al., 2013). Commercially available uricase (Rasburicase sold as Elitek and Fasturtec) was proved to be safe and potentially active drug for the treatment of hyperuricemia . Purified uricase from Pseudomonas has been studied for diagnostic purposes since it exhibits high activity and thermostability in a wide range of temperatures.

There are various reports of enzyme purification either from extraction of animal tissues or from microbial fermentation. The desired enzyme is generally found with various other macromolecules such as proteins, various enzymes, and other undesirable materials. For purification of uricase, organic solvent precipitation, ammonium sulphate fractionation, ion exchange chromatography, xanthine-agarose affinity chromatography, affinity chromatography etc were used (Alamillo et al., 1991). Liu et al., (1994) purified uricase from Candida sp. which was carried out by a procedure in which following steps were involved i.e. ammonium sulphate precipitation and sephadex G200. Then the fractions that had maximum activity were further run on DEAE-cellulose (DE52 chromatography). After purification, the specific activity of uricase was increased from $0.05-12 \mathrm{U} / \mathrm{mg}$; it was also observed that the purified enzyme was stable at $\mathrm{pH}$ 8.5-9.5 and temperature less than $35^{\circ} \mathrm{C}$.

\section{Materials and methods:- \\ Sample Collection:-}

The samples for isolation of microorganisms were collected from various environments where the natural process of uric acid degradation is taking place. Soil samples were collected from different sites including poultry farms and others areas in Kerala, and were transported in sterile bottles to the Microbiology laboratory of St.Peter's College, Kolenchery for bacterial isolation.

\section{Screening and Isolation of bacteria:-}

Soil samples $(1 \mathrm{gm})$ were suspended in $9 \mathrm{ml}$ of sterile double distilled water. This was serially diluted in a series of $9 \mathrm{ml}$ sterile distilled water labeled as $10^{-1}, 10^{-2}, 10^{-3}, 10^{-4}, 10^{-5}$ etc. From this $10^{-2}, 10^{-3}, 10^{-4}, 10^{-5}$ were selected for spread plating. Primary screening of uricase from different samples was performed by inoculating $0.1 \mathrm{ml}$ of the test organisms from different dilutions onto agar plates with uric acid medium (uric acid $0.3 \%$ (w/v), beef extract $0.3 \%$ (w/v), peptone $0.5 \%(\mathrm{w} / \mathrm{v}), \mathrm{NaCl} 0.2 \%(\mathrm{w} / \mathrm{v})$, and agar 2.3\% (w/v) at $\mathrm{pH} 7.5)$ (Monaet al., 2015). Media was sterilized by autoclaving ( $15 \mathrm{psi}, 121^{\circ} \mathrm{C}$, and $\left.15 \mathrm{~min}\right)$. The samples were kept in incubator at $37^{\circ} \mathrm{C}$ for $2-3$ days. The appearance of clear zones around the colonies is an indication for uricase enzyme production. Those with clear zones were re-inoculated on to fresh Uric acid medium to ensure enrichment of uricase producing microorganisms. The samples which showed clear zones were considered as positive samples.

\section{Morphological and cultural characteristics:-}

The morphological identification and cultural characteristics of isolates were examined. Colonies were compared for their diameters, overall colors, texture, size, cell arrangement, elevation and pigmentation. All the isolates were also subjected to microscopic analysis for their characterization and identification by the methods given by Bergey's Manual of determinative bacteriology and by Cappuccino and Sherman, 1999.

\section{Biochemical characterization:-}

Different biochemical tests were analyzed including Indole test, Methyl red test, Vogues- Proskauer test, Citrate utilization test, starch hydrolysis, nitrate reduction, Catalase test, Oxidase test, phenylalanine deamination and sugar fermentation test. 


\section{Molecular Identification of Bacteria:-}

Polymerase chain reaction allows amplification of specific DNA sequences. Pure culture of the target Bacteria was grown overnight on nutrient Broth for the isolation of DNA. The DNA was isolated from the bacteria using phenolchloroform method and 16S rDNA was amplified by Thermocycler (Eppendorff) using the universal primers, 27S and $1492 \mathrm{R}$.

Universal Primer (Lane, 1991):-

27 forward 5AGAGTTTCCTGGCTCAG 3

1492 reverse 5ACGGCTACCTTGTTACGATT 3

The PCR was performed in $50 \mu 1$ reaction mixture containing $5 \mu \mathrm{l}$ of $10 \mathrm{X}$ assay buffer, $4 \mu \mathrm{l}$ dNTP mix, $1 \mu 1$ each of

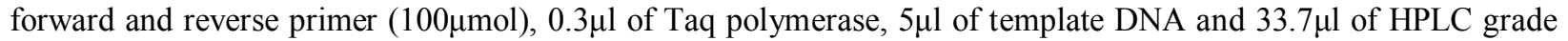
water with the Following amplification for $16 \mathrm{srRNA}$ initial denaturation at $95^{\circ} \mathrm{C}$ for $5 \mathrm{~min}$ followed by 35 cycles of denaturation, annealing and extension $\left(95^{\circ} \mathrm{C}\right.$ for $30 \mathrm{sec}, 52^{\circ} \mathrm{C}$ for $45 \mathrm{sec}$ and $72^{\circ} \mathrm{C}$ for $\left.90 \mathrm{sec}\right)$ and final extension at $72^{\circ} \mathrm{C}$ for $10 \mathrm{~min}$ followed by hold for infinity at $4^{\circ} \mathrm{C}$.

The amplified 16S rDNA PCR product was sequenced using automated sequencer (SciGenom Labs Pvt Ltd, Kochi, India.). The Sequence Similarity search was done for the 16S rDNA sequence using online search tool called BLAST (http://www.ncbi.nlm.nih.gov/blast/). The unknown organism was identified using the maximum aligned 16SrRNA sequences available in the GenBank of NCBI through the BLAST search. The best sequence alignment results were noted.

Optimization of Culture Conditions on uricase activit:-

In order to determine effects on uricase production, the selected bacterial isolates were grown in Uric acid broth and incubated at various parameters. The influence of all factors on enzyme activity was determined by measuring uricase activity at varying $\mathrm{pH}$ values from 6 to 9 , temperature varying from $25^{\circ} \mathrm{C}$ to $40^{\circ} \mathrm{C}$, salinity varying from $0.1 \%$ to $1.5 \%$. Carbon and nitrogen sources have been replaced with various substances. The influence of the factors on enzyme activity was determined by measuring uricase activity.

\section{Submerged fermentation process:-}

For preparation of standard inoculum, those isolates showed a maximum zone of hydrolysis were cultured in $20 \mathrm{ml}$ Uric acid medium [composition : uric acid $0.3 \%(\mathrm{w} / \mathrm{v})$, beef extract $0.3 \%(\mathrm{w} / \mathrm{v})$, peptone $0.5 \%(\mathrm{w} / \mathrm{v}), \mathrm{NaCl} 0.2 \%$ (w/v), and $\mathrm{pH}$ adjusted to 7.5 ] individually and incubated at $37^{\circ} \mathrm{C}$ for $24 \mathrm{~h}$. This was used as inoculums for the fermentation medium. The composition of fermentation medium was same as of inoculums medium. Fermentation was carried out in $250 \mathrm{ml}$ Erlenmeyer flasks, each containing $100 \mathrm{ml}$ sterile uric acid medium and inoculated with $5 \%$ of standard inoculums (containing 2-3.5x106 cells $/ \mathrm{ml}$ ). The flasks were incubated at $37^{\circ} \mathrm{C}$ on a rotary shaker at 150 RPM for 48h (Mona et al., 2015).

\section{Preparation of crude enzyme:-}

After incubation, the cultures were centrifuged at $1600 \mathrm{RPM}$ for $20 \mathrm{~min}$ at $4^{\circ} \mathrm{C}$ and supernatant was used as a source of crude enzyme. The crude enzyme solution was utilized for determination of enzyme activities.

\section{Uricase enzyme assay:-}

First, $2.5 \mathrm{ml}$ of $0.001 \%$ uricacid solution that was mixed with $0.1 \mathrm{~mol} / \mathrm{L}$ of boric acid buffer solution $(\mathrm{pH} 8.5)$ was placed in to a $3 \mathrm{ml}$ quartz cuvette. Then $0.5 \mathrm{ml}$ of diluted enzyme solution was added and mixed approximately. Then, the absorbance changes at $293 \mathrm{~nm}$ and $25^{\circ} \mathrm{C}$ were continuously measured and the activity was measured using the following formula.

Activity $(\mu / \mathrm{ml})=\left(\Delta \mathrm{OD}_{293 \mathrm{~nm}} \times \mathrm{df} \times 0.5\right)$

Here df refers to enzyme dilution factor, $\Delta \mathrm{OD}_{293 \mathrm{~nm}}$ refers to the absorbance change, and t refers to time in minutes. An enzyme activity unit was defined as the amount of enzyme needed to catalyze $1 \mu \mathrm{mol}$ of uric acid oxidation per minute at $25^{\circ} \mathrm{C}$ and $\mathrm{pH} 8.5$ (Cheng et al, 2012).

\section{Protein determination:-}

Protein concentrations in a crude sample were determined by using a Folin Lowry method (Lowry et.al., 1951) with bovine serum albumin (BSA) as a standard. 
Optimization of uricase production:-

The optimum parameters were determined for uricase production from the efficient isolates. The uricase fermentation was carried out at different ranges of parameters including temperature, $\mathrm{pH}$, salinity, carbon and nitrogen source. After fermentation at different parameters the crude enzyme sample was collected from each to check the enzyme activity.

\section{Effect of temperature on uricase production:-}

The sterile uric acid media $(100 \mathrm{ml})$ was prepared in different $250 \mathrm{ml}$ Erlenmeyer flasks and inoculated with $5 \%$ inoculums. Each flask was incubated at different temperatures such as $25^{\circ} \mathrm{C}, 30^{\circ} \mathrm{C}, 35^{\circ} \mathrm{C}$, and $40^{\circ} \mathrm{C}$ for 48 hours at $150 \mathrm{rpm}$. The enzyme activity was estimated.

\section{Effect of $\mathrm{pH}$ on uricase production:-}

The uric acid media $(100 \mathrm{ml})$ was prepared in different $250 \mathrm{ml}$ Erlenmeyer flasks and was adjusted to different $\mathrm{pH}$ such as $6,7,7.5,8$, and 9using $0.1 \mathrm{~N} \mathrm{NaOH}$ and $0.1 \mathrm{~N} \mathrm{HCl}$. After sterilization flasks were inoculated with $5 \%$ inoculums. The flasks were incubated at $37^{\circ} \mathrm{C}$ for 48 hours at $150 \mathrm{rpm}$. The enzyme activity was estimated.

\section{Effect of salinity on uricase production:-}

The uric acid media $(100 \mathrm{ml})$ was prepared in different $250 \mathrm{ml}$ Erlenmeyer flasks and was adjusted to different concentrations of salinity using $0.1 \%, 0.2 \%, 0.5 \%, 1.0 \%$, and $1.5 \% \mathrm{NaCl}$. After sterilization flasks were inoculated with $5 \%$ inoculums. The flasks were incubated at $37^{\circ} \mathrm{C}$ for 48 hours at $150 \mathrm{rpm}$. The enzyme activity was estimated.

\section{Effect of carbon source on uricase production:-}

The uric acid media $(100 \mathrm{ml})$ was prepared in different $250 \mathrm{ml}$ Erlenmeyer flasks and was supplied with different Carbon sources such as Dextrose, Maltose, Sucrose, Starch and Carboxy Methyl Cellulose (CMC) in 1\% concentration. After sterilization flasks were inoculated with $5 \%$ inoculums. The flasks were incubated at $37^{\circ} \mathrm{C}$ for 48 hours at $150 \mathrm{rpm}$. The enzyme activity was estimated.

\section{Effect of nitrogen source on uricase production:-}

The uric acid media $(100 \mathrm{ml})$ was prepared in different $250 \mathrm{ml}$ Erlenmeyer flasks and was supplied with different Nitrogen sources such as Yeast extract, Urea, Ammonium nitrate, and Casein in $0.2 \%$ concentration. After sterilization flasks were inoculated with $5 \%$ inoculums. The flasks were incubated at $37^{\circ} \mathrm{C}$ for 48 hours at $150 \mathrm{rpm}$. The enzyme activity was estimated (Anderson et al., 2012).

\section{Partial purification of uricase:-}

The cells grown under all the optimum conditions studied were used for maximum uricase production. The cells were collected, washed, and broken down, and cell proteins were precipitated with $40 \%$ ammonium sulfate. . The resultant precipitate was dissolved in $5 \mathrm{ml} 0.02 \mathrm{M}$ tris- $\mathrm{HCl}$ buffer of $\mathrm{pH} 8.5$ and dialyzed overnight against 2 liters of the same buffer in a cellophane bag. The precipitate was applied to a column of DEAE cellulose for further purification.

A glass column $(1.5 \times 30 \mathrm{~cm})$ was packed with DEAE-cellulose. The concentrated and dialyzed cell free supernatant was applied to a column, which previously was equilibrated with $0.01 \mathrm{M}$ borate buffer(pH 8.5$)$. The column was washed with 20 times volumes of $0.01 \mathrm{M}$ borate buffer, $\mathrm{pH} 8.5$ at a flow rate of $40 \mathrm{ml} / \mathrm{hour}$ and the bound proteins were eluted with a linear $\mathrm{NaCl}$ gradient $(0-1 \mathrm{M})$ in the same buffer and analyzed by UV spectrophotometer at $280 \mathrm{~nm}$. Fractions containing uricase enzyme were pooled and concentrated using ammonium sulphate precipitation method as described above.

\section{Results:-}

\section{Isolation and screening:-}

Seventeen different samples were collected from different sites including poultry farms and agricultural areas. The samples were kept for incubation in uric acid medium and the zone of clearance around the bacterial colonies were observed. About eight samples showed good results from which 3 strains labeled as S2, S11, S16 with efficient uricase production were isolated and used for further analysis (Figure 1).The morphological and biochemical characteristics of the samples are given. (Table land Table 2). 


\section{DNA isolation:-}

DNA was isolated from the samples S2, S11, and S16 and visualized using Agarose gel electrophoresis. The DNA obtained was viewed as fluorescent bands under UV light and the image was recorded using Vilber Lourmat gel Documentation unit and stored for further analysis (Figure 2).

\section{Polymerase chain reaction:-}

After the PCR reaction the samples were loaded in 1.5\% Agarose gel and visualized in UV light. Cultures S2 and S16 were amplified with forward and reverse primers specific for 16srDNA and generated specific amplicons (Figure 3). The most promising uricase producing strain S16 was identified as Ochrobactrum anthropi by $16 \mathrm{~S}$ rRNA gene sequence analysis (Figure 4).

\section{Optimization of culture condition:- Effect of temperature:-}

An experiment was designed to establish the optimum temperature for bacterial growth to produce high quantity of uricase enzyme. The results showed that $40^{\circ} \mathrm{C}$ was optimum temperature for maximum uricase production by the isolates .Maximum yield obtained was $0.0029 \mathrm{U} / \mathrm{mg}$ protein for S2 and $0.007 \mathrm{U} / \mathrm{mg}$ protein for S16 (Figure 5).

\section{Effect of PH:-}

The purpose of this experiment was to determine the optimum $\mathrm{pH}$ for maximum uricase production by the isolates. The results showed that the optimal $\mathrm{pH}$ for the growth of S2and $\mathrm{S} 16$ was attained at $\mathrm{pH} 9.0$ for maximum uricase production. Maximum uricase production obtained was found to be $0.0096 \mathrm{U} / \mathrm{mg}$ protein for S2 and $0.0108 \mathrm{U} / \mathrm{mg}$ protein for S16. Further, the enzyme activity was found to be decreasing with pH 7.5>8>6.5>6. (Figure 6).

\section{Effect of salinity:-}

This experiment was performed to find out the optimum salinity for uricase production. The bacterium was inoculated on culture media adjusted with different saline concentration $(0.1,0.2,0.5,1.0$ and $2.5 \%)$. The results showed that $0.5 \%$ salinity was suitable for uricase production by the isolates. Maximum uricase activity at $0.5 \%$ salinity was found to be $0.0113 \mathrm{U} / \mathrm{mg}$ protein for $\mathrm{S} 2$ and $0.0078 \mathrm{U} / \mathrm{mg}$ protein for S16. (Figure 7).

\section{Effect of carbon source:-}

Different carbon sources (dextrose, sucrose, maltose, starch, and cellulose) were tested in order to determine their influences for uricase production. The results showed that, the large amount of uricase (30U/ml) was produced in the medium containing dextrose. Maximum uricase production obtained with dextrose as carbon source was found to be $0.031 \mathrm{U} / \mathrm{mg}$ protein for S2 and $0.0074 \mathrm{U} / \mathrm{mg}$ protein for S16. . Enzyme activity decreases with Sucrose, Maltose, Starch, and Cellulose respectively. (Figure 8).

\section{Effect of nitrogen source:-}

The present experiment was conducted to test the suitability of different nitrogen sources (yeast extract, urea, casein and ammonium nitrate) for bacterial growth. The result showed that yeast extract proved to be the best nitrogen source for maximum uricase production by the two isolates. Maximum uricase production was obtained with Yeast extract was found to be $0.043 \mathrm{U} / \mathrm{mg}$ protein for samples S2 and $0.0675 \mathrm{U} / \mathrm{mg}$ protein for S16. Enzyme activity decreases with Casein, Ammonium Nitrate, and Urea respectively (Figure 9).

\section{Partial purification of uricase:-}

These experiments were carried out to obtain the pure uricase from the crude enzyme extract which was collected from the fermentation experiments of Ochrobactrum anthropi. The obtained uricase after partially purification with $40 \%$ ammonium sulphate was dialyzed and dissolved in $1 \mathrm{ml}$ of $0.01 \mathrm{M}$ borate buffer. Then applied to the top of DEAE-cellulose column chromatography $(1.5 \mathrm{X} 30 \mathrm{~cm})$ which previously equilibrated with $0.01 \mathrm{M}$ buffer at $\mathrm{pH} 8.5$ at room temperature. The purification results which summarized in Table (3) record that the enzyme was purified almost 1.26 - fold with a specific activity of $.046 \mathrm{U} / \mathrm{mg}$ protein.

\section{Acknowledgement:-}

Authors thank to Kerala State Council for Science Technology and Environment (KSCSTE) for providing the grant to carry out this work. 
Table 1:- Morphological identification.

\begin{tabular}{|l|l|l|l|}
\hline Morphology & S2 & S11 & S16 \\
\hline Size of colony & 2mm & $4 \mathrm{~mm}$ & $6-8 \mathrm{~mm}$ \\
\hline Margin & Entire & Entire & Adulate \\
\hline Elevation & Flat & Slightly raised & Flat \\
\hline Pigmentation & Yellow & Creamy yellow & White \\
\hline Opacity & Opaque & Translucent & Opaque \\
\hline Gram staining & $\begin{array}{l}\text { Gram negative rods (Pink } \\
\text { coloured) }\end{array}$ & $\begin{array}{l}\text { Gram negative cocci (Pink } \\
\text { coloured) }\end{array}$ & $\begin{array}{l}\text { Gram negative rods (Pink } \\
\text { coloured) }\end{array}$ \\
\hline
\end{tabular}

Table 2:- Biochemical identification.

\begin{tabular}{|c|c|c|c|c|c|c|c|c|c|c|c|}
\hline $\begin{array}{l}\text { Sampl } \\
\text { e }\end{array}$ & $\begin{array}{l}\text { Indol } \\
\text { e test }\end{array}$ & $\begin{array}{l}\mathrm{M} \\
\mathrm{R} \\
\text { tes } \\
\mathrm{t}\end{array}$ & $\begin{array}{l}\mathrm{V} \\
\mathrm{p} \\
\text { tes } \\
\mathrm{t}\end{array}$ & $\begin{array}{l}\text { Citrat } \\
\text { e test }\end{array}$ & $\begin{array}{l}\text { Ureas } \\
\text { e test }\end{array}$ & $\begin{array}{l}\text { Lactose } \\
\text { fermentati } \\
\text { on }\end{array}$ & $\begin{array}{l}\text { Maltose } \\
\text { fermentati } \\
\text { on }\end{array}$ & $\begin{array}{l}\text { Glucose } \\
\text { fermentati } \\
\text { on }\end{array}$ & $\begin{array}{l}\text { Starch } \\
\text { hydrolys } \\
\text { is }\end{array}$ & $\begin{array}{l}\text { Catalas } \\
\text { e test }\end{array}$ & $\begin{array}{l}\text { Oxidas } \\
\text { e test }\end{array}$ \\
\hline S2 & -ve & $\begin{array}{l}+\mathrm{v} \\
\mathrm{e}\end{array}$ & $\begin{array}{l}- \\
\text { ve }\end{array}$ & -ve & -ve & -ve & -ve & -ve & $+v e$ & $+v e$ & -ve \\
\hline S11 & -ve & -ve & $\begin{array}{l}- \\
\text { ve }\end{array}$ & $+v e$ & +ve & -ve & -ve & -ve & $+v e$ & $+v e$ & +ve \\
\hline S16 & -ve & -ve & $\begin{array}{l}- \\
\text { ve }\end{array}$ & +ve & +ve & -ve & -ve & -ve & $+v e$ & $+v e$ & +ve \\
\hline
\end{tabular}

Table 3:- Purification of uricase from Ochrobactrum anthropi.

\begin{tabular}{|l|l|l|l|}
\hline Purification stage & Enzyme activity (IU/mL) & $\begin{array}{l}\text { Specific activity } \\
\text { (U/mg protein) }\end{array}$ & Purification factor \\
\hline Crude & 0.067 & 0.036 & - \\
\hline $40 \%$ ammonium sulfate & 0.047 & 0.043 & 1.20 \\
\hline Dialysis & 0.028 & 0.043 & 1.21 \\
\hline DEAE Cellulose column & 0.018 & 0.046 & 1.26 \\
\hline
\end{tabular}
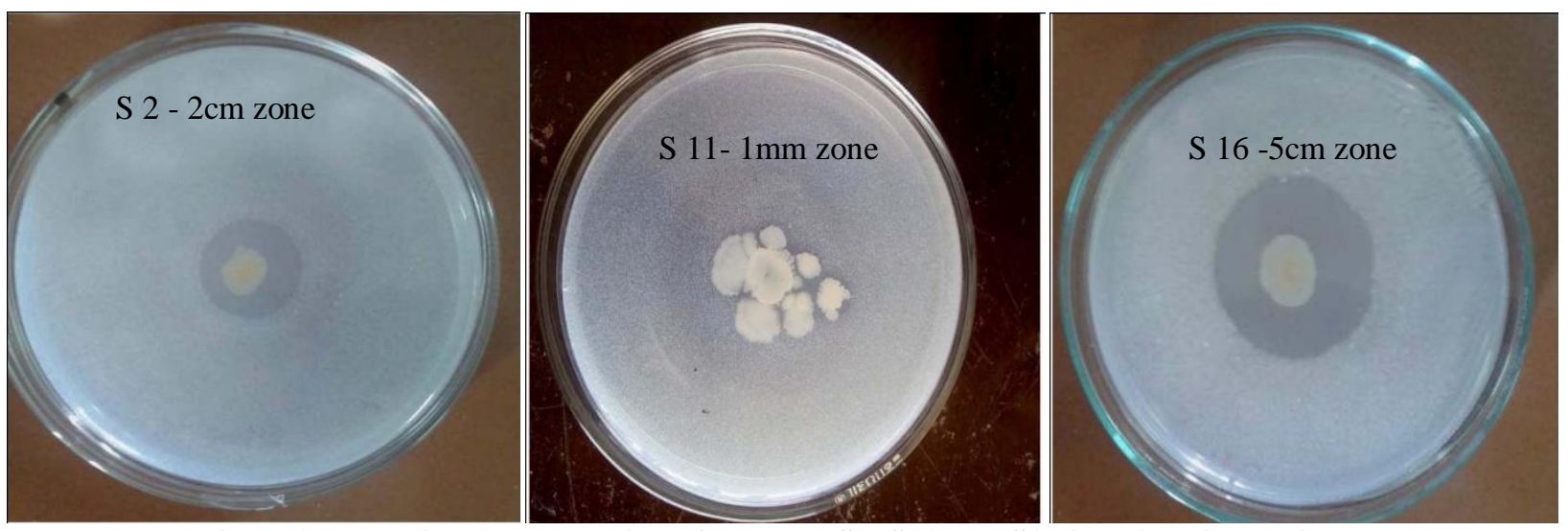

Figure1:- Isolation and screening of samples S2, S11 and S16 in uric acid medium. 


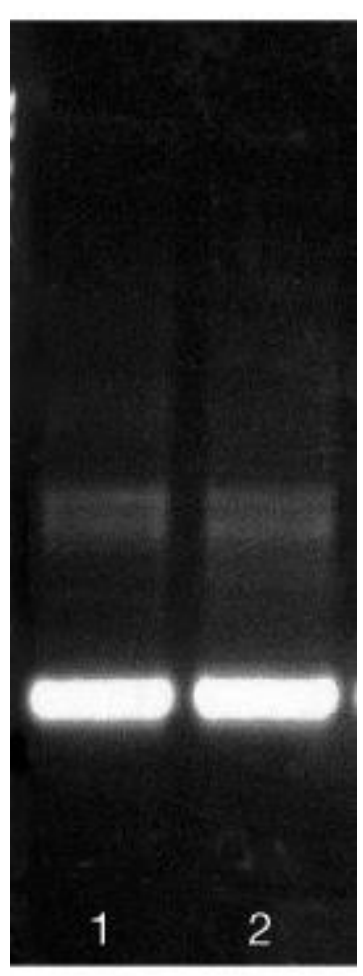

Figure 2:- DNA isolation

Lane 1 - Sample 2; Lane 2 - Sample 16

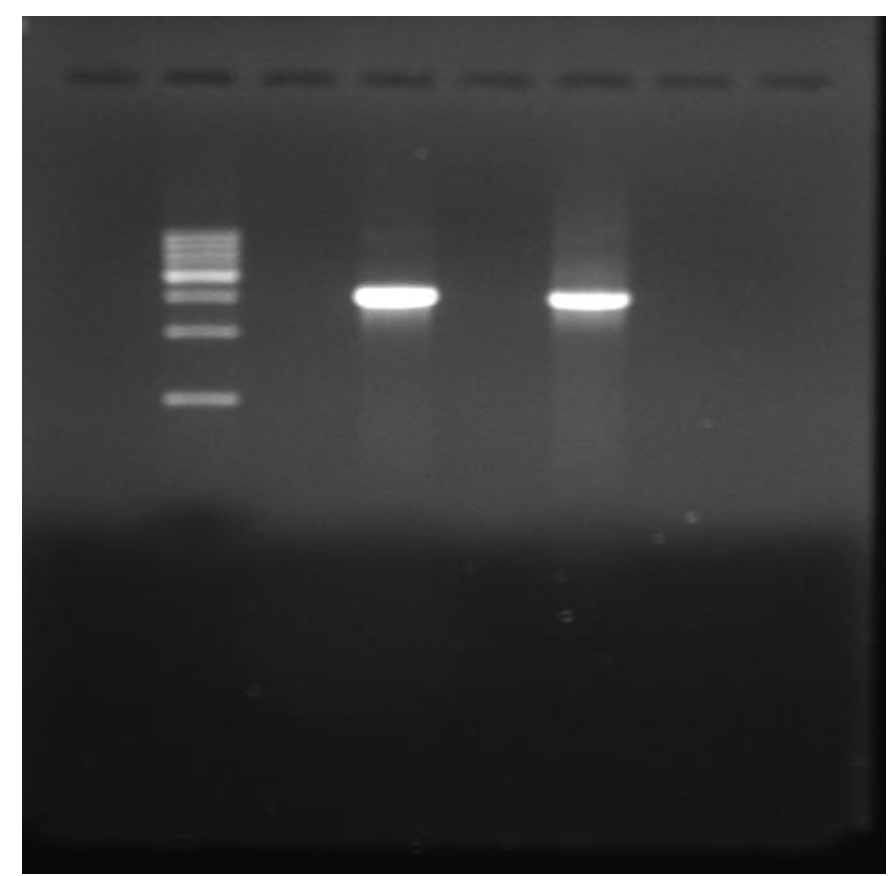

Figure 3:- Polymerase chain reaction

Lane 2: 500 bp marker; Lane 4: Sample 2; Lane 6: Sample 16

Step 1: $95^{0}$ C 5minutes - Initial Denaturation; Step2: $95^{0}$ C 30 minutes - Denaturation; Step 3: $52^{0}$ C 45 seconds Anealing; Step 4: $72^{0}$ C 90 seconds - Extension;

Go to step 2 (35 cycles)

Step 5: $72^{0} \mathrm{C} 10$ minutes - Final extension; Step 6: $4^{0} \mathrm{C}$ for Hold - For Cooling 


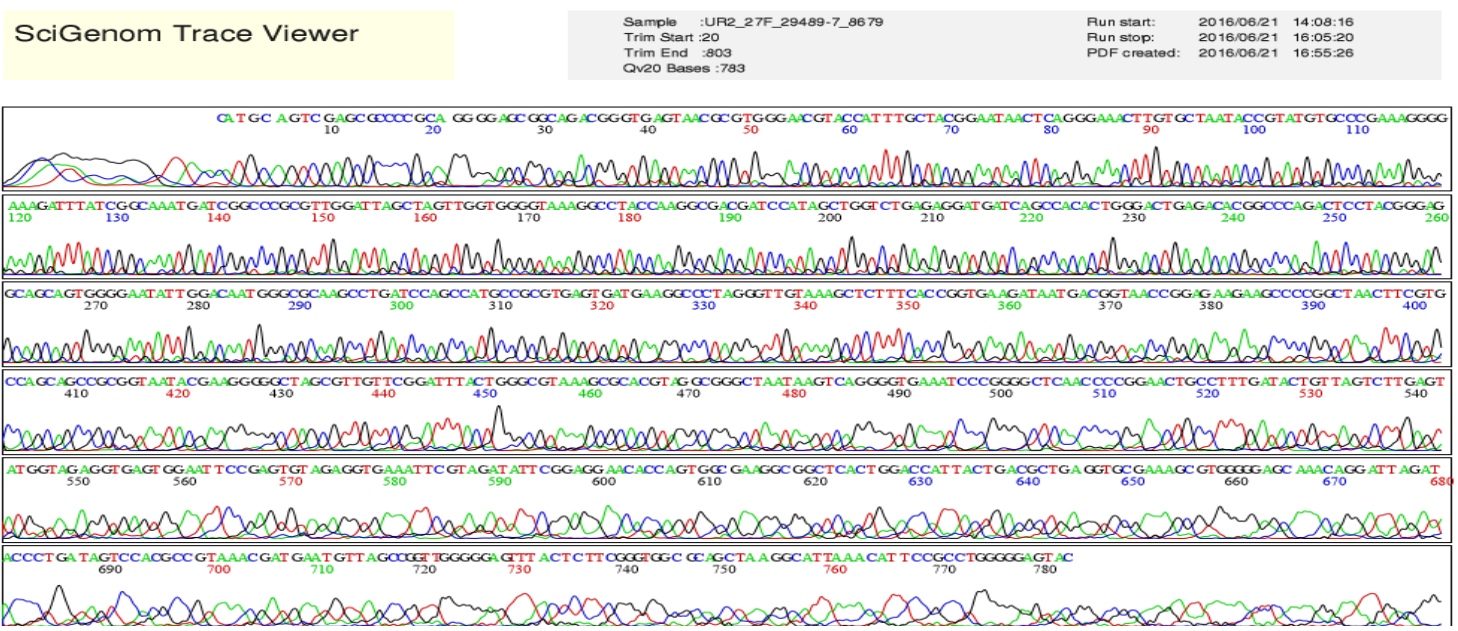

Figure 4:- The sequencing report of Ochrobactrum anthropi.

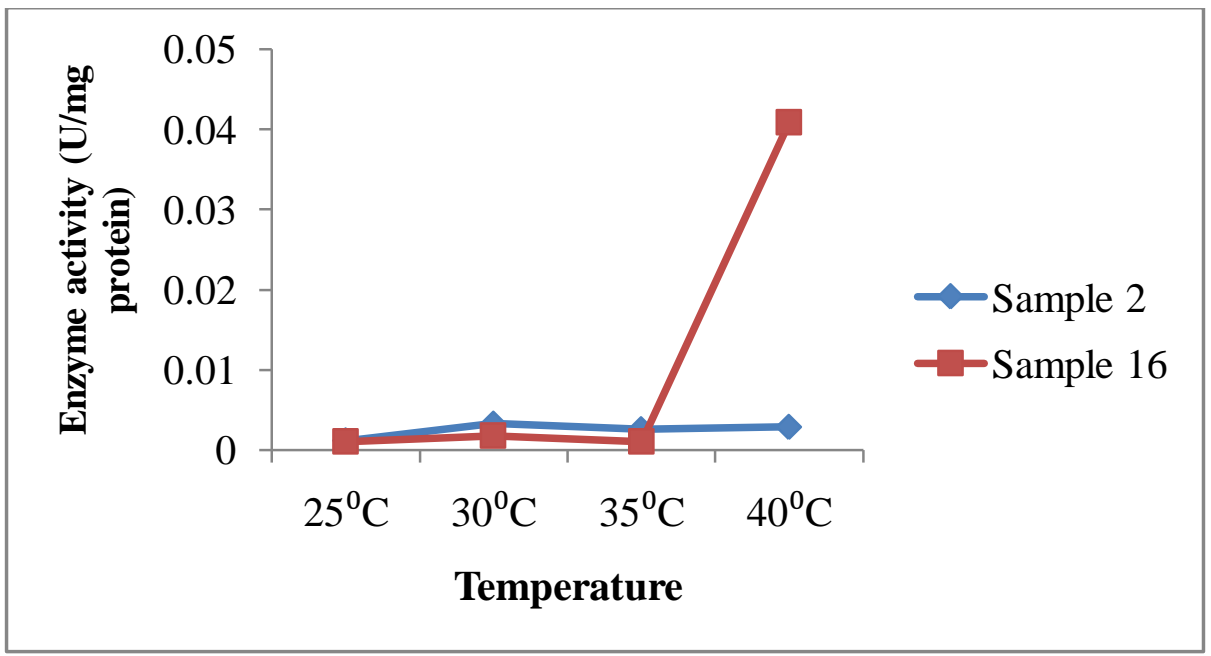

Figure 5:- Effect of temperature on enzyme activity.

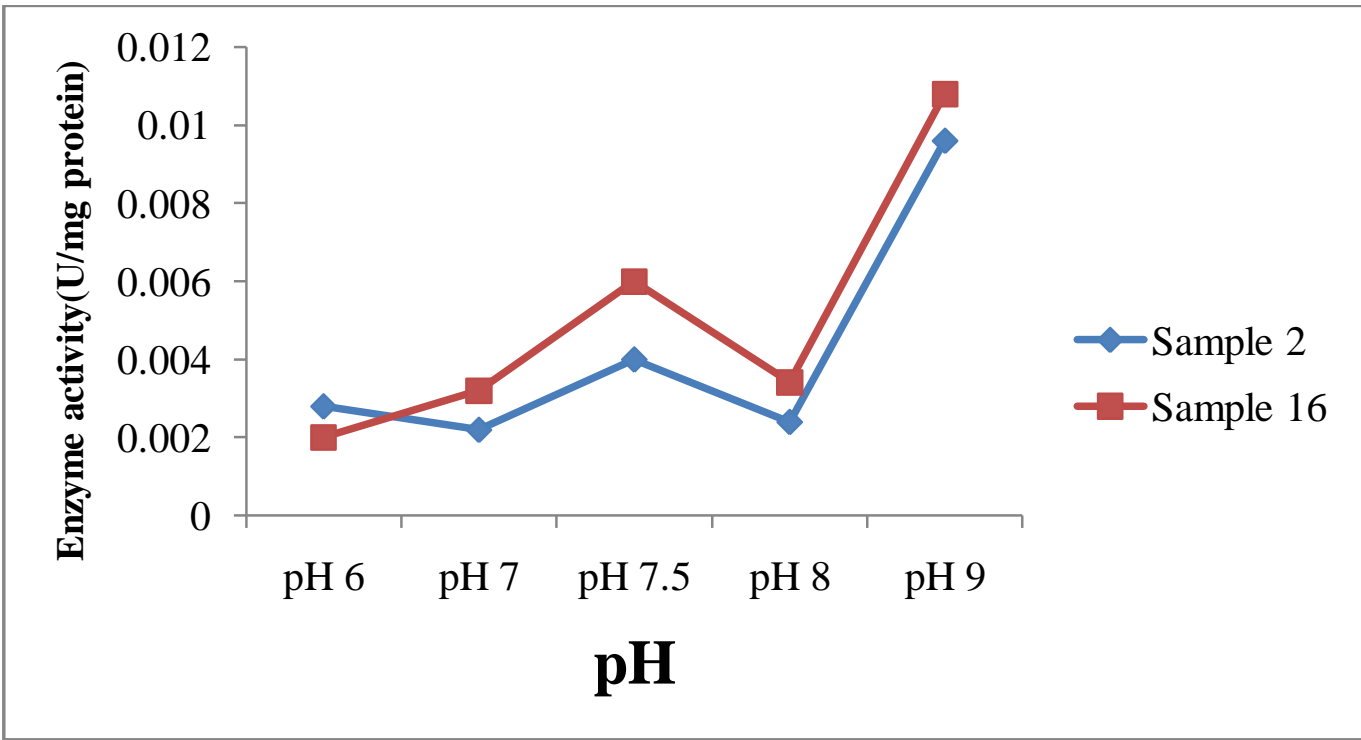

Figure 6:- Effect of pH on enzyme activity. 


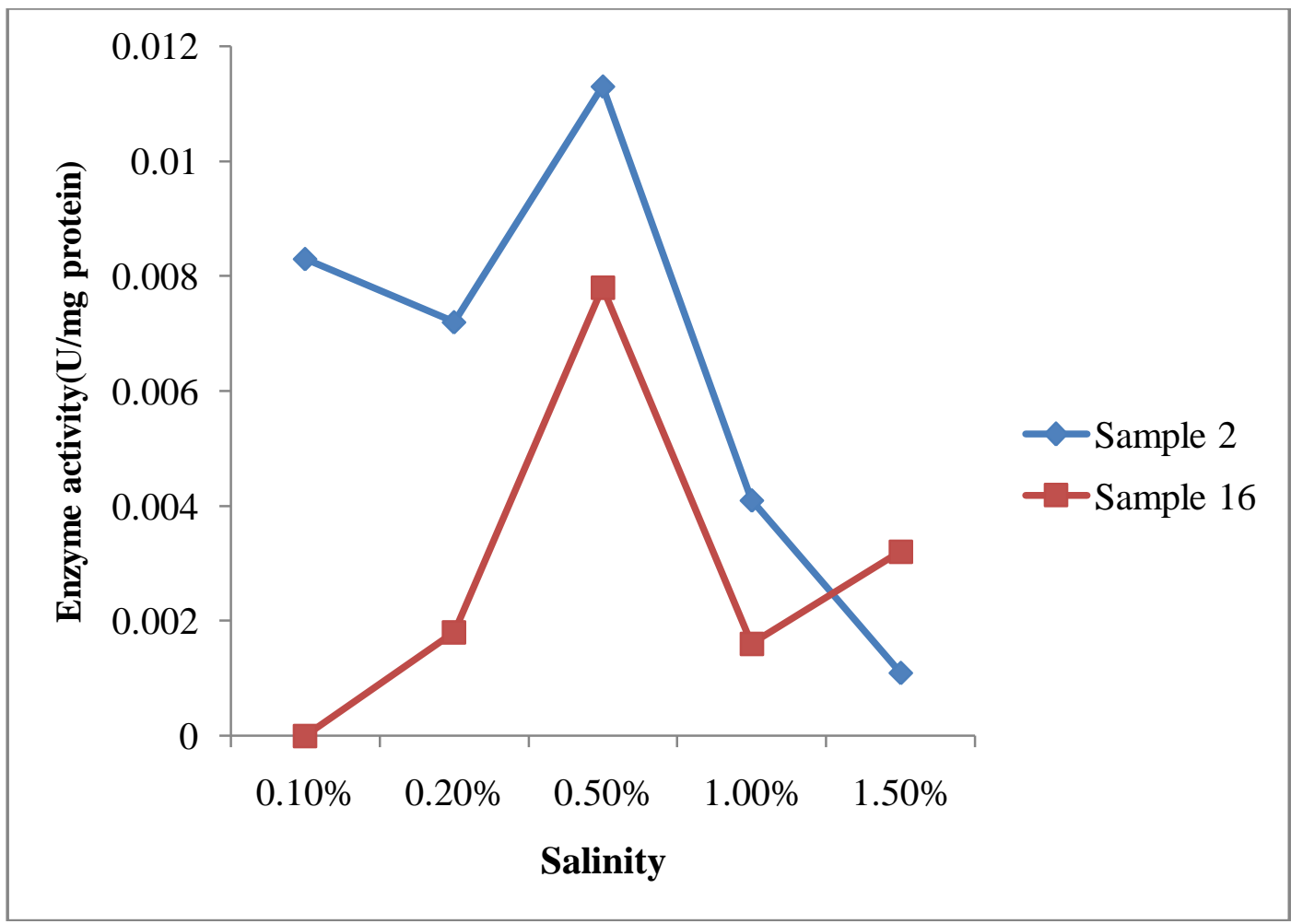

Figure 7:- Effect of salinity on enzyme activity.

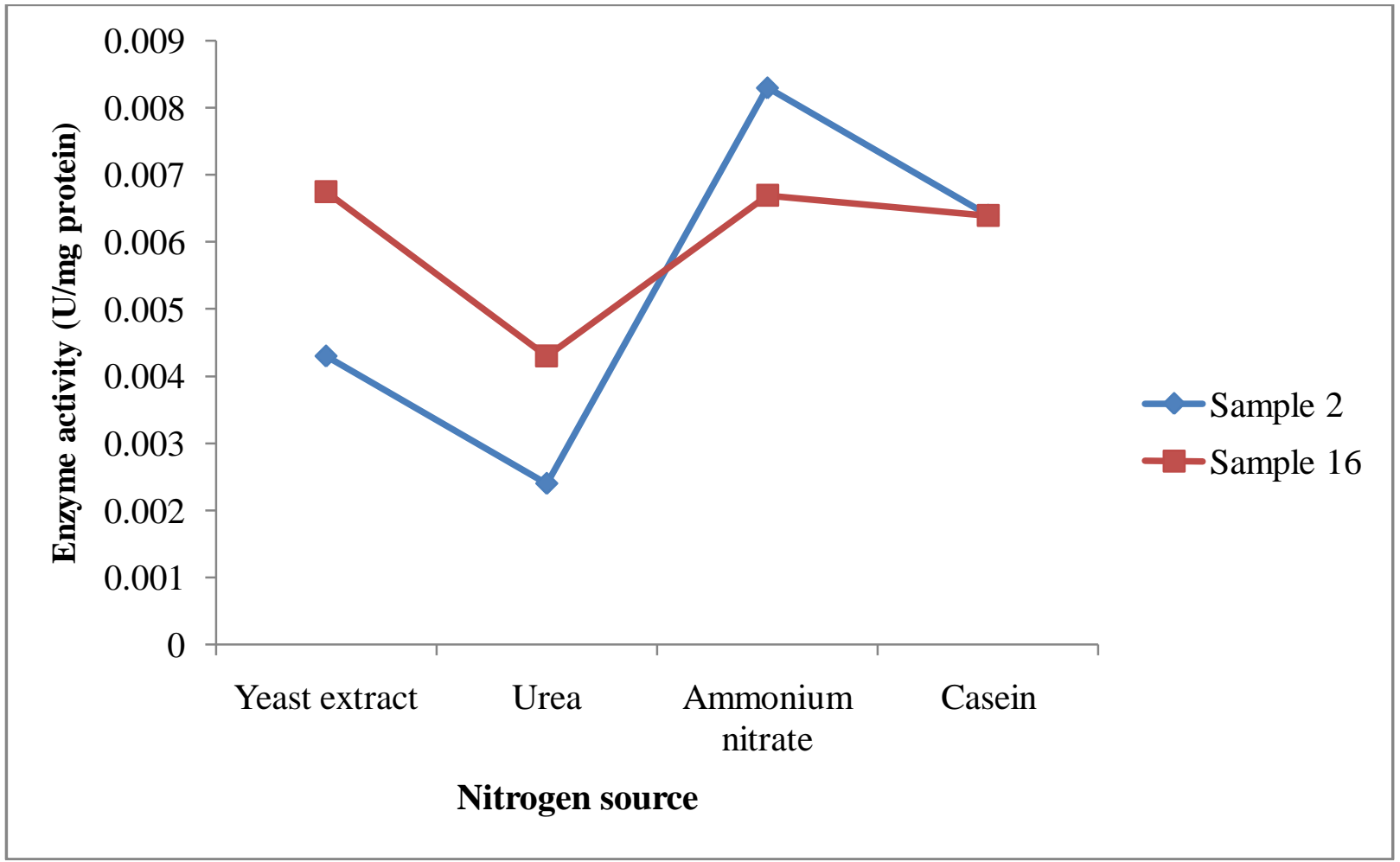

Figure 8:- Effect of nitrogen sources on enzyme activity. 


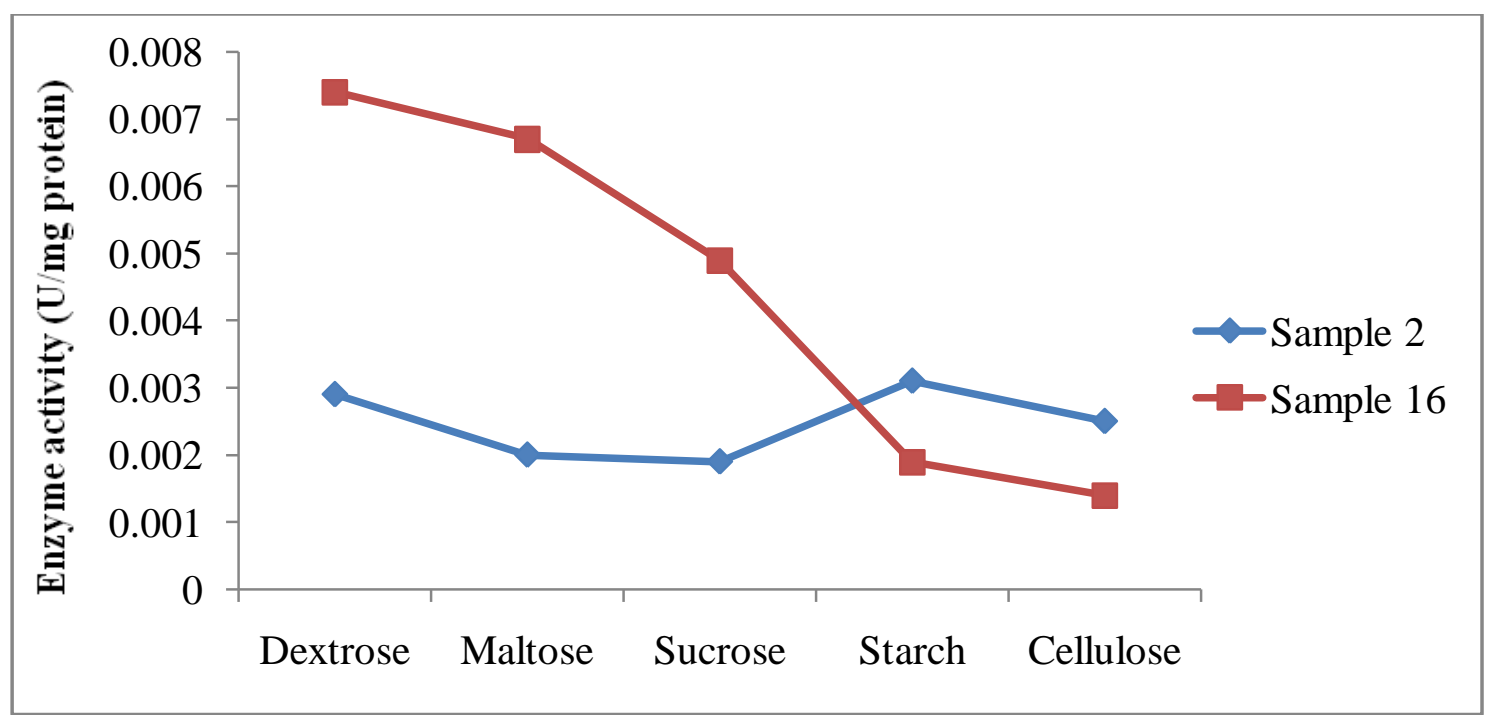

Figure 9:- Effect of carbon sources on enzyme activity.

\section{Discussion:-}

Uricase was isolated from mammalian organisms, but more recently it has been obtained from various fungi and bacteria. The bacterial isolates were recovered from contaminated soils, poultry farms collected from different localities in Kerala.In all cases, the enzyme was found to be inducible, and the presence of uric acid or some other inducer in the medium is necessary for enzyme formation (Azab et al, 2005). Around seventeen bacterial isolates were obtained on nutrient agar. All the isolates were screened on uric acid agar medium and the activity was detected as clear zones accompanying the growth of microorganisms in solid agar (Miad, 1974).

After 2 days at $37^{\circ} \mathrm{C}$, about ten isolates (20\%) produced uricase and the most active intracellular uricase producer based on the zone diameter $(5 \mathrm{~cm})$ was the isolate designated as $\mathrm{S} 16$ obtained from a pet farm waste (Pigeon).

According to morphological, physiological, and biochemical comparison, the three isolates (S2, S11, and S16) were found to be gram negative. The identification results were confirmed using $16 \mathrm{~S}$ rDNA, which is considered a powerful tool for deducing phylogenetic and evolutionary relationships among bacteria, archaebacteria, and eukaryotic organisms (Olemezoglu, 2012). The most potent strain among the isolates S16 was subjected to 16S ribosomal RNA gene sequencing and identified as Ochrobactrum anthropi .

The optimization of fermentation conditions, (physical and chemical parameters) is important in the development of any fermentation process owing to their impact on the economy and practicability of the process. In the present study $40^{\circ} \mathrm{C}$ was found to be optimum temperature for O.anthropi. Data illustrated in Graph (Figure 5) clearly indicated that the highest enzyme activity of O.anthropi was found to be $0.0071 \mathrm{IU} / \mathrm{mg}$ protein at $40{ }^{\circ} \mathrm{C}$. The enzyme activity was found to increase with the increase in temperature. It is in agreement with the recent study that the maximum uricase production by Pseudomonas aeruginosa was achieved at $35^{\circ} \mathrm{C}$ temperature (Anderson and Vijayakumar. 2012).

Like temperature, $\mathrm{pH}$ is also an important factor that influences the uricase yield. The results clearly showed that uricase production reached its maximum at $\mathrm{pH}$ of 9.0 for O.anthropi and the enzyme activity was found to be 0.0060 IU/mg protein. A similar finding was also observed by Atalla et al., 2010, that the highest uricase enzyme production was achieved at $\mathrm{pH} 9.0$ by Pseudomonas aeruginosa (Khucharoenphaisan and Sinma, 2011).

In this study, the effect of $\mathrm{NaCl}_{2}$ was examined in the range of $0.1 \%-1.5 \%$ for bacterial growth. Surprisingly $0.5 \%$ of $\mathrm{NaCl}_{2}$ concentration was found to be optimum for Ochrobactrum anthropi.

Similar finding was also observed recently that $1.5 \%$ salinity was suitable for $P$. aeruginosa growth for uricase production (Anderson and Vijayakumar, 2012). In the present experiment dextrose was found to be the best carbon source for Ochrobactrum andthropi growth. In previous studies dextrose was shown to be the best carbon source for 
Pseudomonas aeruginosa (Khucharoenphaisan and Sinma, 2011). Similarly in the case of nitrogen source yeast extract was found to be the best for $O$. anthropi. Similar findings were also observed for $P$. aeruginosa (Khucharoenphaisan and Sinma, 2011).

In enzyme fermentation process, the crude extracts contain contaminants (organic acids and other metabolites). So different purification methods should be done to extract the required product. (Mukesh Kumar et al., 2012).The uricase enzyme was purified using ammonium sulphate precipitation, dialysis and DEAE ion exchange chromatography. The specific activity observed by $40 \%$ ammonium sulphate precipitation was found to be $0.0431 \mathrm{IU} / \mathrm{mg}$ protein and with regard to purification it showed 1.2 fold purification. The specific activity and fold purification after dialysis were $0.0434 \mathrm{IU} / \mathrm{mg}$ protein and 1.21 respectively. DEAE ion exchange chromatography yielded specific activity and fold purification of $0.0455 \mathrm{IU} / \mathrm{mg}$ protein and 1.26 respectively. In conclusion, pure uricase can be produced from bacteria and can be used to lower uric acid levels and assay uric acid in blood or urine. However, advanced purification and characterization techniques must be done for the effective production.

\section{References:-}

1. Adamek, V, Kralova, B, Suchova, M, Valentova, O, and Demnerova, K. (1989). Purification of microbial uricase. J Chromatography, 497: 268- 275.

2. Alamillo, J.M., Cárdenas, J, and Pineda, M. (1991). Purification and molecular properties of urate oxidase from Chlamydomonas reinhardti. Biochemistry and Biophysics Acta, vol 1076, pp 203-208.

3. Ammar, M, S., Elwan, S, H., El-Desouky, E, M. (1988). Purification and some properties of uricase from Aspergillus flavus S-97. Egypt J Microbiol 23: 83-87.

4. Ammar, M, S., Elwan, S, H., El-Shahed, A, S. (1987): A uricolytic Streptomycin albogriseolus from an Egyptian soil. Taxonomy and uricase production and properties. J Microbiol., 22: 261-279.

5. Anderson, A, and Vijayakumar, S. (2012): Isolation and Optimization of Pseudomonas aeruginosa for uricase production. Intl J Pharma Biosci., 3: 143-150.

6. Atalla, M, M., Farag , M,M., Eman, R, H .( 2012). Optimum conditions for uricase enzyme production by Gliomastix gueg. Malaysian J Microbiol 5: 45-50.

7. Atalla, M, Mabrouk., Eman, R, Hamed., Farag, M, M and Nohad, E, Ahmed. (2010): Purification and Characterization of Uricase enzyme produced Gliomastix gueg. Gate2Biotech., 11: $1-13$.

8. Azab, E, A., Aly, M, M, and Fareed, M, F. ( 2005). Studies on uricase induction in certain bacteria. Egypt J Biol 7: 44-54.

9. Cheng, X., Yang, B., Liu, D., He, L, J, and Chen G. (2012) Genetic Engineering of Bacteria that can Produce Urate Oxidase. Intern Med 2:114.

10. James, G, Cappuccino, and Natalie, Sherman. (2011): Microbiology: A Laboratory Manual. 9th Edition. Pearson Education., Benjamin Cummings Science publication. 23 - 48.

11. Khucharoenphaisan, K, and Sinma, K. (2011): Production and partial characterization of uric acid degrading enzyme from new source Saccharopolyspora sp.PNR11. Pak J Biol Sci., 14(3): 226-231.

12. Liu, J., Li, H, Liu., and X, Zhou.(1994). Purification and properties of uricase candida species and its application of uric acid analysis in serum. Appl Biochem Biotechnol. 47(1): 57-63.

13. Magda, ALY., Sanaa, TORK., Saleh, AL-GARNI1., and Reda ALLAM1(2013). Production and characterization of uricase from Streptomyces exfoliates UR10 isolated from farm wastes. Turk J Biol. 520 529

14. Mead, G, C. (1974)Anaerobic utilization of uric acid by some group D streptococci. J Gen Microbiol 82: 421423.

15. Mona, I, Shaaban., Eman, Abdelmegeed, and Youssif, M, Ali. (2015): Cloning, Expression, and Purification of Recombinant Uricase Enzyme from Pseudomonas aeruginosa Ps43 Using Escherichia coli, J Microbiol Biotechnol. 25(6): $887-892$.

16. Mukesh, Kumar, D., J, Poovai, C., L, Puneeth, Kumar., Sushma, Saroja, Y., Manimaran, A, and Kalaichelvan, P,T. ( 2012): Optimization of Bacillus cereus MRK1 cellulase production and its Biostoning activity., Der Pharmacia Lettre. 4 (3): 881-888.

17. Olmezoğlu, E., Herand, B, K.., Oncel, M, S., Tunc, K, and Ozkan M.( 2012). Copper bioremoval by novel bacterial isolates and their identification by $16 \mathrm{~S}$ rRNA gene sequence analysis. Turk J Biol36: 469-476.

18. Su-Hua, Huang, and Tung-Kung, Wu. (2004). Modified colorimetric assay for uricase activity and a screen for mutant Bacillus subtilis uricase genes following StEP mutagenesis. Eur J Biochem. 271(3): 517 - 523. 